\title{
The Juridical Origins of the International Patent System: Towards a Historiography of the Role of Patents in Industrialization
}

Ikechi Mgbeoji

Osgoode Hall Law School of York University, imgbeoji@osgoode.yorku.ca

Source Publication:

Journal of the History of International Law. Volume 5, Issue 2 (2003), p. 403-422.

Follow this and additional works at: https://digitalcommons.osgoode.yorku.ca/scholarly_works (c) (i) $(9)$

This work is licensed under a Creative Commons Attribution-Noncommercial-No Derivative Works 4.0 License.

\section{Recommended Citation}

Mgbeoji, Ikechi. "The Juridical Origins of the International Patent System: Towards a Historiography of the Role of Patents in Industrialization." Journal of the History of International Law 5.2 (2003): 403-422.

This Article is brought to you for free and open access by the Faculty Scholarship at Osgoode Digital Commons. It has been accepted for inclusion in Articles \& Book Chapters by an authorized administrator of Osgoode Digital Commons. 


\section{The Juridical Origins of the International Patent System: Towards a Historiography of the Role of Patents in Industrialization}

\section{Introduction}

The concept and institutionalization of patents is controversial. It is however prudent to define a patent before examining its history and greater ramifications. A patent may be defined as a "government grant of the exclusive rights to make, use, and sell the substance of a recent invention. The life or period of a patent is limited and starts when a patent document is issued by the government." As an adjective, the term "patent" derives from the Latin verb patere, which means "to be open." In relation to a patent of invention, the document is an "open letter addressed to the public" denoting a clearly defined invention and conferring specific property interests over a limited period of time. ${ }^{3}$ In modern times, patents have retained their original character as governmental grants or privileges. ${ }^{4}$ As Fritz Machlup and other scholars have pointed out, what the patentee gets is "the right to exclude other persons for a limited time from making a commercial use of the invention without his/her consent."s

* LL.B., (Nigeria), B.L., (Lagos), LL.M., J.S.D. (Dalhousie) Assistant Professor, Osgoode Hall Law School, Toronto, Canada. This article is dedicated to Judge Ronald St.J. Macdonald of Halifax for his many years of mentorship and friendship.

I What Is A Patent? (American Bar Association, Section of Patent, Trademark and Copyright Law, Chicago, 1981)

2 William Aldous et al. (eds.), Terrell On The Law Of Patents (London: Sweet \& Maxwell, 1982) at 1.

3 Fritz Machlup, An Economic Review Of The Patent System (Study of the Subcommittee on Patents, Trademarks, and Copyrights of the Committee on the Judiciary, United States Senate, 85 th Congress, Second Session. Study No. 15) 1.

4 Laurinda Hicks and James Holbein, "Convergence Of National Intellectual Property Norms In International Trading Agreements" (1997), 12 American University Journal of International Law and Policy 769.

5 Machlup, supra note 3 at 2. See also J.M. Laine, "Infringement Of Patents By Intention" (1901), 17 The Law Quarterly Review 201; Paul Mathely, "The New French Patents Acts" (1979), Industrial Property Law 124; Dana Rohrabacher and Paul Crilly, "The Case For A Strong Patent System" (1995), 8 Harvard Journal of Law and Technology 263. 
For clearly ideological reasons, the history of the institution of patents is beset with competing claims of origin. Without a doubt, the most common and indeed, ideologically driven claim is the contention by various proponents of strong and global patent regimes that the patent system owes its origin to the British industrial revolution and the Statute of Monopolies. There is thus a general assumption, almost an axiom among patent lawyers, that patents have a causal or organic link with inventiveness and industrialization. ${ }^{6}$

For example, an English patent attorney in attributing the success of the British industrial revolution to the patent concept declared that "the patent system was our invention, and it gave us the first place among nations in industry for over 200 years." Shunning the patriotic fervour of the British attorney, a German patent attorney vouched that "the countries whose industries take foremost place, also rank highest in patent policy." ${ }^{2}$ These panegyrics to patents remain an abiding refrain for those who advocate the creation of patent systems in industrializing or non-industrialized States. The sup-

6 Robert Sherwood, Vanda Scartezini and Peter Dirk Siemsen, "Promotion Of Inventiveness In Developing Countries Through A More Advanced Patent Administration" (1999), 39 The Journal of Law and Technology 473; Robert Sherwood, "Human Creativity For Economic Development: Patents Propel Technology" (2000), 33 Akron Law Review 1; Donald Gregory, Charles Saber and Jon Grossman, Introduction To Intellectual Property Law (Washington: BNA Books, 1994); William Kingston, Innovation, Creativity And The Law (Dordrecht: Kluwer Academic Publishers, 1990).

7 H. Stafford Hatfield, Inventions And Their Use In Science Today (London: 1939); as quoted in Eric Schiff, Industrialization Without National Patents - The Netherlands, 1869-1912, Switzerland, 1850-1907 (New Jersey: Princeton University Press, 1971); Harvey Bale, "Patent Protection And Pharmaceutical Innovation" (1996-1997), 29 International Law and Politics 95 . Another concurring voice enthused that "it was not ... by accident that the patent system had its origin in England, nor that the industrial revolution was the inevitable consequence." See H.G. Fox, as quoted in Schiff at 9. H.G. Fox continues with this line of debate when he argued that, "the dross of abuse and impropriety in the monopoly system had to be refined in the furnace of experience before the gold of the present patent system emerged to take its place as the greatest contributory factor to modern industrial progress." Ibid.

8 Quoted in Schiff, ibid. at 12. These eulogies to the patent system are not limited to the British or continental Europeans. Across the Atlantic, a United States patent attorney vowed that "the strongest evidence of the value of the American patent system is our industrial economy, which has been built largely upon a groundwork of patented inventions." Ibid. Adding a flavour of democratic heroism to this ode to patents, another American patent attorney declared that "the defence of the democratic world depends largely on American industry, which owes its present strength in large part to traditional American patent policy." See Karl Lutz, "A Proper Public Policy On Patents: Are We Adopting The Soviet View?" (1951), 37 American Bar Association Journal 943. According to the American Patent Society, "the patent system is the foundation of American enterprise. It has ... contributed to the achievement of the highest standard of living that any nation has ever enjoyed." Schiff, ibid. 
posed organic link between patents and inventiveness, particularly, during the industrial revolution is so entrenched in the discourse on the historical necessity of patents that it is virtually heretical for any scholar of patents to argue otherwise.

Taking these statements ex facie, it is tempting to conclude that the patent system originated during the British industrial revolution and that it is one of the greatest achievements of human ingenuity without which mankind, particularly, the non-industrialized world would languish in primitive anarchy and the tedium of stone age existence. Surprisingly, the proof, if any, of the causal relationship between patents and inventiveness and indeed, the historicity of the patent system in the British industrial revolution era is very questionable. Indeed, on a closer analysis, the hypothesis that patents propel inventiveness is founded on a concoction of anecdotal inferences ${ }^{9}$ and debatable assumptions on complex factors. Thus, in spite of repeated, generalized and polemical claims ${ }^{10}$ of an automatic causal link between patent regimes and inventiveness, the "most well-reasoned studies of patent systems"1" have failed to establish a link between inventiveness and the patent system, especially, in the industrial revolution.

More importantly, as this article would demonstrate, the patent system pre-dated the British industrial revolution by nearly 200 years and thus could not have been the determinative impetus for that memorable epoch in human history. To the extent that this article argues that the patent system did not originate with the Statute of Monopolies and thus played no critical role in the industrial revolution in Britain, it is fair to assume that the views expressed are inconsistent with the dominant narratives of the history and effects of patents. Given the controversial and indeed, ideological tenor of the various claims by many "patent systems" as to authorship of the patent system, this article engages in an historical reconstruction of the evolution and development of the modern juridical system of patents.

In my analysis, various competing "histories" of the patent system are examined, evaluated and their veracity as the origin of the patent system are resolved. In my view, the competing claims to the origins of the patent systems can only be resolved on the basis of certain criteria which constitute the irreducible essence of a patent system. In other words, in determining whether any of the claimants is the undoubted progenitor of the modern patent system, regard must be paid to the following criteria:

9 Robert Merges, "Battle Of Lateralisms: Intellectual Property And Trade" (1990), 8 Boston University International Law Journal 239; Robert Sherwood, Intellectual Property And Economic Development (Colorado: Westview, 1990) at 2. But see Robert Sherwood, "Intellectual Property Systems And Investment Stimulation: The Rating Of Systems In Eighteen Developing Countries" (1996-1997), 37 IDEA 261.

${ }^{10}$ Schiff, supra note 7.

$"$ Frederick Abbott, et al. (eds.), The Making of The International Intellectual Property System (The Hague, Kluwer Publications, 1999). 
1. whether the patent grant was an exercise of governmental powers designed to provide for the patentee exclusive right to the commercial exploitation of a clearly defined invention;

2. whether the grant was premised on the criterion of novelty of invention rather than a grant of monopoly for already existing trade or business, or grant for the exploitation of discoveries such as natural ores or substances;

3. whether the grant was clearly designed to promote industrialization in the widest meaning of the term, and finally;

4. whether the grant was the predictable result of a legal system instead of a singular or ad hoc grant to an inventor.

In this exercise, seven well-known claimants are evaluated. These include, (1) the Andaman traditional concept of patents, (2) the classical Greek notion of patents, (3) the British "patent" issued to John Kemp in 1331, (4) the Tyrolean patents of 1409, (5) the Florentine patent issued to Filippo Brunelleschi, (6) the Venetian patent statute of 1474 and finally (7) the British Statute of Monopolies.

In concluding this article, I argue that on the basis of available historical data and the juridical elements of these rival claimants vis- $a$-vis their essential similarity with modern patent systems, the Venetian Law of 1474 is the progenitor of the modern patent system. Accordingly, to the extent that the patent system did not originate in Britain during the industrial revolution, it would be erroneous to make a case for patents on the so-called "historical necessity" theory. There is no historical nexus between patents, inventiveness and the British industrial revolution. The case for strong patent may be made on other grounds but not on the purported historical links between the patent system and the British industrial revolution.

\section{The concept of patents amongst the Andaman Islanders, the Kai, the Koryak and the Plains Indians}

R.H. Lowie's anthropological study shows that the concept of patents was highly developed amongst the Andaman Islanders, the Kai, the Koryak and the Plains Indians. ${ }^{12}$ The Andaman Islanders have origins clouded in mystery. Living in lush islands with pristine beaches, it is an intriguing piece of social organization that there are notions of patent "grants" on novel creations amongst these peoples. However, upon a closer examination of the notion of patents as understood by the Andaman, it is clear that there is a fundamental difference between their exceptional concept of patents and the more generally known European patent system.

12 R.H. Lowie, Primitive Society (New York, 1920) at 235-243. See also Peter Drahos, A Philosophy Of Intellectual Property (Dartmouth, Aldershot: 1996). 
First, in contrast to the underlying patent conception of the inventive process as a solitary and individual effort, the communal way of life of the Andaman and the nonindustrial basis of their notion of patents disqualify the Andaman patent "system" from serious consideration as the progenitor of the modern patent system. Second, under the Andaman notion, information embedded in the "patent" is for the most part construed as a public good. ${ }^{13}$ As Peter Drahos points out, "these societies (the former) were in contrast to Western approaches, more concerned with restricting the transferability of such rights"14 and not with the idea of an exclusive right of an individual-as-creator in the invention.

More importantly, the discovery that the Andamans have a notion of patents was made nearly 100 years ago at a period when the dominant patent system was already well-known and established. Finally, the institution of patents is primarily dependent on a culture of writing which is absent in the Andaman variant. Consequently, an obscure and oral notion of patents among an isolated colony of peoples far removed from the demands of Western industrialization cannot possibly be the modern progenitor of the institution of patents.

Ideologically, patents constitute a congealed form of a particular cultural ideology, philosophy and jurisprudence of property and economics. ${ }^{15}$ Conceding that as conceptions of property evolve, the content of patents concept equally changes, there is no evidence to suggest that the Andaman notion or ideology of patents is similar to the Western philosophy of property. The philosophical implication is that the Western approach and conception "commodifies" and "thingifies" the processes and outputs of human labour and imposes private "toll-gates" or "fences" around such knowledge on the concept of ius excluendi and ius prohibendi. ${ }^{16}$ Ex necessitate, the Andaman notion

13 Drahos, supra at 61; Thomas Franck, "Community Based On Autonomy" in Jonathan Charney, et al. (eds.), Politics, Values And Function In International Law In The 21st Century (The Hague: Martinus Nijhoff Publishers, 1997) at 57.

${ }^{14}$ Ibid. See Byron Good, Medicine, Rationality And Experience - An Anthropological Perspective (Cambridge: University Press, 1994) at 5-20. See also Ann McElroy and Patricia Townsend, Medical Anthropology In Ecological Perspective (Boulder, Colorado: Westview Press, 1989).

15 The concept of property has since the hazy origins of jurisprudence dominated legal thought. The literature is enormous and beyond the ambit of this article. However, the following texts would reward reading : Kenneth Vandevelde, "The New Property Of The Nineteenth Century: The Development Of The Modern Concept Of Property" (1980), 29 Buffalo Law Review 325; Emily Sherwin, "Two-and Three-Dimensional Property Rights" (1997), 29 Arizona State Law Journal 1075; Joseph Singer and Jack Beerman, "The Social Origins Of Property" (1993) Vol. VI, No. 2, Canadian Journal of Law and Jurisprudence 217; R.S. Bhala, "The Basis Of The Right Of Property" (1982), 11 Anglo-American Law Review 57; R.S. Bhalla, "Legal Analysis Of The Right To Property" (1981), 10 Anglo-American Law Review 180.

${ }^{16}$ G.W.F. Hegel, Philosophy Of Right (1821; T.M. Knor tr., Oxford University Press: Clarendon, 1952,1 st ed., 1967 reprint) at 151. 
of patents is culturally distinct and dissimilar to the patent system in its Western cultural foundations. ${ }^{17}$

The patent system was designed to promote the employment of capital and industry in new profitable directions. This ideology of the patent system was only an historical motivation but remains a characteristic feature of the contemporary patent law system..$^{18}$ Hence, cultural and ideological differences relating to the industrial utility of patents as a criterion for patentability of inventions inexorably leads to the conclusion that a non-Western society ${ }^{19}$ such as the Andaman Islanders could not have afforded the philosophical template for the evolution and development of the patent system.

\section{Ancient Greek "patents"}

Having disposed of the anthropological studies suggesting an Andaman link to patents, the next in line in terms of antiquity are the ancient Greek and Roman ideas about incentives for creativity. Here, it must be noted that there are fragmentary and elusive allusions in classical literature to a purported Greek origin of the concept of patents. These allusions ostensibly derive from the common notion that the granting of certain privileges may encourage inventiveness or spur creativity amongst the populace of a given society.

In this context, it seems that the first recorded classical reference in the Western world to the idea of patents was Aristotle's account of the proposal by Hippodamus of Miletos. The idea was rejected by Aristotle who feared that it would lead to artificial scarcity of goods and social instability. ${ }^{20}$ In addition to Aristotelian anecdotes on the concept of patents, the Greek historian Phylarchus in the Banquet Of The Learned traces the concept of rewarding novel inventions with a monopoly right to the accounts of the Greek colony of Sybaris known for luxurious living and indulgence circa 500 B.C. According to Phylarchus, the Sybarites granted a monopoly of one year to whoever prepared the most unusual and outstanding dish. ${ }^{21}$ Similarly, the early Romans

17 Michael Gadbaw and Timothy Richards (eds.), Intellectual Property Rights: Global Consensus, Global Conflict? (Boulder, Colorado: Westview Press, 1988) at 18.

18 For a succinct account and analysis of the problematic nature of theories on patents, see Samuel Oddi, "Un-Unified Theories Of Patents - The Not-Quite-Holy Grail” (1996), 71 Notre Dame Law Review 267.

19 Susan Tiefenbrun, "Piracy Of Intellectual Property In China And The Former Soviet Union And Its Effects Upon International Trade: A Comparison" (1998), 46 Buffalo Law Review 1; Tao-Tai Hsia and Kathryn Haun, "Laws Of The People's Republic Of China On Industrial And Industrial Property” (1973-1974), 38 Law and Contemporary Problems 274.

${ }^{20}$ Robert Merges, Peter Menell and Mark Lemley, Intellectual Property In The New Technological Age 2nd ed., (New York: Aspen Law \& Business, 2000)

${ }^{21}$ H. Foster and Robert Shook, Patents, Copyrights \& Trademarks (New York: John Wiley \& Sons, 1989) 3. 
rewarded their inventive citizens by exempting them from normal civic duties such as conscription in warfare.

While these accounts have their undoubted merit in conferring antiquity on the notions of rewarding creative people, there is no evidence to suggest or support the implication that the Sybarites had an institutionalized mechanism for the evaluation of novel inventions and for the granting of patent-like privileges. Nor is there any reliable evidence to support any contention that the Sybarites adopted such a "system", as it were, towards the industrialization of the State. More importantly, although the ancient Greeks rewarded originators of new ideas, they could not conceive that such originators of new ideas possessed property interests or rights over the new ideas.

In sum, the available evidence clearly shows that patents or patent-like protection did not exist in ancient times. ${ }^{22}$ There is no ground or basis for tracing the historical origins of the modern patents to the anecdotes of Aristotle or the musings of Phylarchus. Hence, the search for the origin of patents has to be focused elsewhere, particularly, medieval Western Europe. As Harold Wegner has rightly argued, "if one considers a patent system as requiring the grant of an exclusive right to exclude others from commercialization of an invention relating to technology, the origins of the patent systems of today must be traced back to two pathways from Europe that originated in the first half of this millennium." ${ }^{23}$ I shall now turn to Europe of the first half of the last millennium.

\section{The British "patent" of 1331 issued to John Kemp}

Before turning to the Europe of the first half of the last millennium, it is necessary to dispose of another claimant to the authorship of the patent system. There are scholarly writings suggesting that the letters patent issued to John Kemp in 1331 is the progenitor of the modern patent system. ${ }^{24}$ This claim can be summarily dealt with on the ground that the letter to John Kemp was to enable him bring to England his servants and apprentices to practice the art of weaving in England. Given that this and similar "patents" were designed to import existing trades to England, such claims lack merit as they were not issued in respect of new inventions.

\section{The Tyrolean patent regime circa 1300-1400}

Erich Kaufer's groundbreaking research traces the historical origins of the modern patent system to Germanic developments arising from the Tyrolean region in respect of claims for mines. ${ }^{25}$ The theory of Germanic roots of the modern patent system has

\footnotetext{
${ }^{22}$ Harold Wegner, Patent Harmonization (Sweet \& Maxwell, 1993) at 2. Hereinafter, Wegner.

${ }^{23}$ Wegner, at 2.

24 J. Gordon, "Patent Law Reform" (1906), 55 Journal of the Society of Arts 26.

${ }^{25}$ Erich Kaufer, The Economics of The Patent System (Harwood Academic Publishers, 1989).
} 
been examined by some of the leading scholars of patent law, particularly, Harold Wegner. ${ }^{26}$ For reasons which appear below, it is difficult to accept Kaufer's hypothesis of a Tyrolean origin of the modern patent system. First, the Germanic patents on mining water technology issued in Tyrole circa 1300 were principally designed as rewards for "wasserkunste" - water mines - for the successful mining in depleted ore regions. As Wegner has observed, "the Alps were an iron ore mining area from at least the time of the Celtic settlement. In such mining areas, there was a long common law tradition concerning the mining, timber use, and water use property rights of those who were first to 'invent' an ore site."'27

As new iron ore sites were "invented" in Saxony, Silesia and Bohemia, Wegner notes that the miners brought their common law with them. In such circumstances, the law on "invention" or iron ore sites and the "patents" for such inventions became "incorporated into the decisions of specialized mining courts and into the Constitutiones Juris Metallici promulgated by King Wenceslaus II in the year 1300."28 Other Tyrolean laws included the Schladminger Bergbrief of 1408 under which Henricus von Heslingen was awarded a privilege to exploit an ore mine and "use the needed water and timber according to the common law prevailing in Germany." 29

It is interesting that the basis of the word "invention" which is the ultimate key to the world of inventions and the patent system had a meaning closer to what we would now call "discovery" of new ore resources, than the meaning accepted under modern patent law. ${ }^{30}$ Clearly, the Tyrolean "patent" grant was not for what we would construe as inventions in modern times. Rather, it was a regime that had everything to do with mining or exploitation of iron ore deposits and the protection of the interests of miners in the products of the mines. The Tyrolean "patents" were thus akin to a mining or hunting license rather than a patent for invention in the modern sense of the word. Consequently, the Tyrolean "patents for invention" were not proper patents.

However, it must be conceded that the Tyrolean regime afforded a body of principles on which subsequent and more patent-like institutions would be built. This refinement would occur in Venice but prior to the Venetian refinement of the crude Tyrolean regime and the emergence of a full-fledged patent regime there, it is proper to examine and evaluate the impact of the Tyrolean regime on Florence circa 1421.

${ }^{26}$ Harold Wegner, "TRIPS Boomerang-Obligations For Domestic Reform" (1996), 29 Vanderbilt Journal of Transnational Law 535 at 538. Compare with, Mladen Vukmir, "The Roots Of Anglo-American Intellectual Property Law In Roman Law” (1991), 32 IDEA 123.

27 Wegner, supra note 22 at 2.

28 Ibid.

29 Ibid.

${ }^{30}$ Ibid. 


\section{The Florentine patent grant to Filippo Brunelleschi circa 1421}

As already evident, the concept of patents, albeit crude, was already coalescing into a discernible regime of Western jurisprudence in the medieval era. ${ }^{31}$ Its maturation as a regime or legal institution for the protection of new, useful and industrially replicable inventions was to await the fallout in Florence of dramatic circumstances which Owen Lippert has likened to "blackmail." ${ }^{32}$ Here in 1421, the medieval Florentine architect and inventor, Filippo Brunelleschi, who had attained immortal fame by his completion of the cupola of the dome, invented an iron clad sea-craft christened the "Badalone" which he claimed could transport marble across the lake Arno for the construction of the now famous suspended dome of the cathedral in Florence.

Hauling marble was an incredibly difficult and expensive endeavour but Brunelleschi claimed that his craft could "bring any merchandise and load on the river Arno and on any other river or water, for less money than usual." 33 For fear of having another stealing the fruits of his genius, Brunelleschi refused to disclose his invention unless the city granted him a limited right to sole commercial exploitation of the sea-craft. Florence yielded to his unprecedented demands and on 19 June 1421, granted him a public letter to that effect. ${ }^{34}$ Given its seminal importance in the jurisprudence and history of patents, the text of the "patent" granted to Filippo Brunelleschi is reproduced in extenso below:

[T]he Magnificent and Powerful Lords, Lords Magistrate, and Standard Bearer of Justice:

Considering that the admirable Filippo Brunelleschi, a man of the most perspicacious intellect, industry, and invention, citizen of Florence, has invented some machine or kind of ship, by means of which he thinks he can easily, at any time, bring in any merchandise and load on the river Arno and on any other river or water, for less money than usual, and with several other benefits to merchants and others, and that he refuses to make such machine available to the public, in order that the fruit of his genius and skill may not be reaped by another without his will and

${ }^{31}$ Stephen Ladas, Patents, Trademarks, And Related Rights: National And International Protection (Mass: Harvard University Press, 1975) at 6.

32 Owen Lippert, "One Trip To The Dentist Is Enough" in Owen Lippert (ed.), Competitive Strategies For The Protection Of Intellectual Properties (Vancouver: The Fraser Institute, 1999) at 131.

${ }^{33}$ Brunelleschi's “il Badalone" <www.stanford.edu/ broich/tamingnature/brunelleschi.htm>.

${ }^{34}$ Buce William Bugbee, The Early American Law Of Intellectual Property: The Historical Foundations Of The United States Patent And Copyright Systems (Unpublished Doctoral Thesis) (Ann Arbor, Michigan: University of Michigan Press., 1961) at 70; M.L. Blakeney and J. McKeough, Intellectual Property - Commentary and Materials (Sydney: The Law Books Co. Ltd, 1987). 
consent; and that, if he enjoyed some prerogative concerning this, he would open up what he is hiding and would disclose it to all;

And desiring that this matter, so withheld and hidden without fruit, shall be brought to light to be of profit to both said Filippo and our whole country and others, and that some privilege be created for said Filippo as hereinafter described, so that he may be animated more fervently to even higher pursuits and stimulated to more subtle investigations, they deliberated on 19 June 1421:

That no person alive, wherever born and of whatever status, dignity, quality, and grade, shall dare or presume, within three years next following from the day when the present provision has been approved in the Council of Florence, to commit any of the following acts on the River Arno, any other river, stagnant water, swamp, or water running or existing in the territory of Florence; to have, hold, or use in any manner, be it newly invented or made new in form, a machine or ship or other instrument designed to import, ship, or transport on water any merchandise or any things or goods, except such ship or machine or instrument as they may have used until now for similar operations, or to ship or transport, or to have shipped and transported, any merchandise or goods on ships, machines, or instruments for water transport other than such as were familiar and usual until now, and further that any such or newly shaped machine, etc. shall be burned;

Provided however that the foregoing shall not be held to cover, and shall not apply to, any newly invented of newly shaped machine, etc. designed to ship, transport or travel on water, which may be made by Filippo Brunelleschi or with his will and consent; also, than any merchandise, things or goods which may be shipped with such newly invented ships, within three years following, shall be free from imposition, requirement, or levy of any new tax not previously imposed. ${ }^{35}$

Clearly, as Frumkin rightly argues, the Brunelleschi patent "was a real invention patent, as good in subject matter as any of those dealt with in 1947 by the British Patent Office" ${ }^{36}$ or by any modern patent office. The normative significance of Brunelleschi's patent is that unlike the Tyrolean "patents", it was a patent grant for a true invention rather than a grant for the discovery or sole exploitation of natural resources. Further, its scope and duration were clearly delimited.

However, it must be noted that Brunelleschi's "Badalone" dramatically sank on its first trip on lake Arno. ${ }^{37}$ Nothing is recorded about the details of the failure of "Badalone". No historian is certain as to whether the sinking or loss of the "Badalone" was a result

${ }^{35}$ Frank Prager, "Brunelleschi's Patent" (1946), 28:2 Journal of The Patent Office Society 109; Gustina Scaglia, Brunelleschi: Studies of His Technology and Inventions (Cambrideg, Mass: 1970).

${ }^{36}$ Ulf Anderfelt, International Patent Legislation And Developing Countries (The Hague: Martinus Nijhoff, 1971) 4.

${ }^{37}$ Bugbee, supra note 34 at 8. 
of a flaw in the design or of human error or the malevolence of nature. What is certain is that the "Badalone" sank and that Brunelleschi lost ten years salary and a third of his entire wealth. For a long time thereafter, Florence stopped issuing patents. Brunelleschi's misfortune with the Badalone ought not obscure the focus of this inquiry.

Returning to the central thrust of this article, that is, which patent "system" is the world's oldest patent regime, it is clear that the Florentine patent issued to Brunelleschi was a true patent but considering that it was not the product of a predictable system, and that the "invention" was an unmitigated failure, it cannot be regarded as the world's oldest patent regime. Essentially, the Florentine patent was an ad hoc gesture to Brunelleschi. It was not a system or a regime but a singular, albeit, brilliant adumbration of a full-fledged patent system. Second, the invention was not a workable artifice. These radical factors remove it from the ultimate distinction of being the world's oldest patent regime. Accordingly, in our search for the world's oldest patent system, we have to look beyond medieval Florence.

\section{The Venetian patent statute of $\mathbf{1 4 7 4}$}

It would seem that recovering from the watery debacle on the lake Arno, the concept of patents drifted to neighbouring Venice. Here, there were ad hoc patents issued to various inventors in $1443 .^{38}$ These ad hoc patents, like the Florentine patent grant to Brunelleschi ultimately congealed into what is probably, the first substantive patent statute in the world. ${ }^{39}$ The Venetian Statute of 1474 was enacted with a large majority (116 for to 10 against and 3 abstaining). Although it was written in old Venetian dialect which is somewhat difficult to translate, Professor Luigi Sordelli's translation which is reproduced below is the most widely accepted version. The overt masculinization of the inventive process is also obvious. Owing to its seminal status, the Act is reproduced in extenso.

[T] here are in this city, and also there come temporarily by reason of its greatness and goodness, men from different places and most clever minds, capable of devising and inventing all manner of ingenious contrivances. And should it be provided, that the works and contrivances invented by them, others having seen them could not make them and take their honor, men of such kind would exert their minds, invent and make things which would be of no small utility and benefit to our State. Therefore, decision will be passed that, by authority of this Council, each person who will make in this city any new ingenious contrivance, not made heretofore in our dominion, as soon as it is reduced to perfection, so that it can be used and exercised, shall give notice of the same to the office of our Provisioners of Common. It being forbidden to any other in any territory and place of ours to make any

38 G. Mandich, "Venetian Patents (1450-1550)" (1948), 30 Journal of Patent Office Society 172.

${ }^{39}$ Moureen Coulter, Property in Ideas: The Patent Question In Mid-Victorian Britain (Missouri: The Thomas Jefferson University Press, 1991) at 7. 
other contrivance in the form and resemblance thereof, without the consent and license of the author up to ten years. And, however, should anybody make it, the aforesaid author and inventor will have the liberty to cite him before any office of this city, by which office the aforesaid who shall infringe be forced to pay him the sum of one hundred ducates and the contrivance immediately destroyed. Being then in liberty of our Government at his will to take and use in his need any of the said contrivances and instruments, with this condition, however, that no others than the authors shall exercise them..$^{40}$ [Emphasis supplied]

The Venetian patent statute of 19 March 1474 was radical and pioneering in several respects. ${ }^{41}$ It offered protection for a period of ten years to all inventions, which passed the examinations of the General Welfare Board. In addition, it also provided for punishments for unauthorized use or infringements of patent grants. ${ }^{42}$ Further, Venice instituted a registry of patents in $1474 .^{43}$ Interestingly, Galileo Galilei received a patent under that statute in $1594 .{ }^{44}$ As Wegner further records, from 1490-1550, over 120 privileges were granted "most involving water mills, pumps, dredging machines, and similar mechanical devices." 45

It should be noted that by taking the grant of patents outside the wide ambit of royal favour, the Venetian statute was far ahead of the Stuart Statute of Monopolies, which it antedated by over 150 years. On this basis, the patent granted Jacopo Acontio in 1565 for an actual invention is probably the first English patent as against the earlier grants made for the introduction or importation of already existing skill, trade or industry into England. ${ }^{46}$ Clearly, unless other patent systems can offer evidence of a systematized grant of patents to actual inventions in the era predating the Venetian patent statute of 1474 , it is hardly deniable that the Venetian patent regime is the world's oldest patent system. There is thus a compelling argument that modern European patent system, and indeed, the global systems of patents derive from their Mediterranean forebears rather than the Statute of Monopolies.

\footnotetext{
40 Anderfelt, supra note 36 at 4.

${ }^{41}$ Ladas, supra note 31 at 6-7. It should be noted that invention in the western paradigm was primarily a masculine affair. Women were thought to be incapable of "scientific" abilities. For a fuller account of female contributions to western science and inventiveness, see Autumn Stanley, Mothers And Daughters of Invention (Rutgers University Press, 1993).

42 Coulter, supra note 39 at 9.

${ }^{43}$ Christine Macleod, Inventing The Industrial Revolution: The English Patent System, 1660 1800 (Cambridge: Cambridge University Press, 1988) at 11.

44 Foster and Shook, supra note 21 at 5.

45 Wegner, supra note 22 at 4.

${ }^{46}$ Lynn White Jr., "Jacopo Acontio as an Engineer" (1967), 72 American Historical Review at 432.
} 
The diffusion and spread of the patent concept from the Italian peninsula was not by accident. Rather, a combination of certain factors that led to the decline of Italian preeminence in technology facilitated and encouraged the diffusion of skilled artisans and consequent spread of the patent idea from Italy to central and Western Europe. First, the discovery by medieval seafarers and merchants of a direct sea route to India led to the by-passing of the Italian peninsula and consequently, a decline of commerce in the area. Second, the evolution of modern statehood and the rise of Christian doctrines incompatible with the dominant Roman Catholicism challenged the temporal authority of the papacy in medieval Italy. ${ }^{47}$

The Church's intolerance of these new Christian beliefs and interpretations of the Bible led to a persecution of Italian artisans and innovators who were mostly unorthodox in their religious, scholarly and scientific beliefs. Hence, by a combination of these two factors, Italian artisans started drifting to Western Europe for the proverbial greener pasture and for their personal safety. Of course, these Italian migrants did not leave the patent concept behind them; they took it with them to central and Western Europe. For instance, six of the first nine patents in Brussels were granted to Italians (mainly Venetians). ${ }^{48}$ As Maximillian Frumkin noted, "one way or another, Italian influence shows like a thread in all incipient patent systems"40f Europe.

It is therefore no exaggeration to say that the foundations of most European patent systems, including the British and French patent systems, were built on Italian immigrant skills and concepts. ${ }^{50}$ However, there were some European States like Switzerland which detested the patent system. It bears noting that although the various patent systems in medieval Europe world mutually influenced one another in content and organization, those States designed patent systems and policies in accord with their perceived national interests. ${ }^{51}$ It was the cynical exploitation of patents as a means of "importing" existing trades and technologies which ultimately gave rise to the British Statute of Monopolies.

47 Macleod, supra note 43 at 11.

${ }^{48}$ Bugbee, supra note 34 at 87.

49 Quoted in Macleod, supra note 43 at 1 . For an account of the migration of the patent concept to the United States of America, see Bugbee, supra note 34; Kenneth Burchfiel, "Revising The 'Original' Patent Clause: Pseudo-history In Constitutional Construction" (1989), 2 Harvard Journal of Law and Technology 155.

${ }^{50}$ Frederick Abbott et al., supra note 11 at 228.

51 C. Macleod, "The Paradoxes of Patenting: Invention and its Diffusion in 18th and 19th Century Britain, France and North America" (1991), Technology and Culture 905. For example, the institution of patents was primarily used as means or mechanism for luring foreign skills and industries without fidelity to the criterion of absolute novelty. For instance, in France, Article 3 of the original patent law of 1791, provided that "whoever [is] the first to bring into France a foreign discovery shall enjoy the same advantages as if he were the inventor." 
The political economics of the early patent system obscured the law and procedure of patents in medieval Western Europe. As States deliberately engaged in what J.W. Baxter has aptly termed a regime of "invention by importation, as distinct from inspiration", 52 the patent system became a pliable tool to advance perceived State interests. For instance, William Cecil, (first Secretary of State to Queen Elizabeth the First) by granting patent rights to skilled and entrepreneurial Europeans wishing to emigrate to establish their businesses in England, applied the patent system as a "strategic international trade policy." 53 This was exemplified in the case of the Clothesworkers of Ipswich decided in 1614 where the court held that:

[I]f a man hath brought in a new invention and a new trade within the Kingdom in peril of his life and consumption of his stock, etc., or if a man hath made new discovery of anything, in such cases, the King ... in recompense of his costs and travail may grant by charter unto him that he alone shall use such trade or traffic, not the knowledge of the skill to use it for a certain time because at the first, the people of the kingdom are ignorant..$^{54}$

Although it was in Britain that the instrumentalist exploitation of the patent system reached its nadir, this practice was not limited to the British Isles. In continental Europe, the early French patent system was a regime of privileges without pretensions to originality or inventiveness as a criterion for the grant of patents. For instance, in France, Article 3 of the original patent law of 1791, provided that "whoever [is] the first to bring into France a foreign discovery shall enjoy the same advantages as if he were the inventor." ${ }^{55}$ In the same vein, early Dutch patent law did not require novelty as a criterion for the grant of patents; merely being the first importer or introducer of the trade or art sufficed.

Thus, the pioneering brilliance of the Venetian patent statute of 1474 was grossly distorted and corrupted in the latter medieval era. The prevailing motive and underlying policy amongst the often competing States of Europe was the economic welfare of

52 J.W. Baxter, World Patent Law and Practice, Vol. 2 (London: Sweet \& Maxwell, 1976) at 7.

${ }^{53}$ Robert Merges, Intellectual Property, supra note 20 at 125. See also Cruikshank and Fairweather, The Law of Patents, Designs and Trademarks (International Patent Agency: Glasgow, 1907) at 1. Similarly, in his letter to Thomas Cromwell, Sir Antonio Guidolti proposed a scheme to bring Italian silk-weavers to England but on the condition that a patent should be granted on silk-weaving for 20 years. See Macleod, supra note 43 at 52; Wyndham Hulme, "On the History of Patent Law In the Seventeenth and Eighteenth Centuries" (1902), 18 The Law Quarterly Review 280; James Bakewell, "The American And British Systems Of Patent Law" (1891), 7 The Quarterly Law Review 364. Compare with, Wood Renton, "Patent Right in England and The United States" (1891), 26 The Law Quarterly Review 150.

${ }^{54}$ The Clothesworkers of Ipswich Case, 78 E.R.147. Reproduced in Cruikshank, at 6.

55 (As quoted in) Edith Penrose, The Economics of the International Patent System (Connecticut: Greenwood Press, 1974) at 70. 
the State and the attainment of a pre-eminent position in the sciences and technology, especially in textiles, mining, metallurgy and ordinance. In other words, it was the invention and not the inventor per se who was the primary focus of the patent system. The discretionary nature of patent grants degenerated to egregious abuses, especially, by necessitous British monarchs who desperately needed to keep their fawning courtiers or sustain their high living. For example, as Holdsworth records:

[James] the First was always hard up; and for a consideration he was prepared to grant many privileges both of the governmental and of the industrial varieties. Of the second of these varieties of grants the following are a few examples: grant of an exclusive right to export calfskins; grant of an exclusive right to import cod; grant of an exclusive right to make farthing tokens of copper. ${ }^{56}$

This abuse contributed immensely to the malodorous air of privilege attached to early English patents. In consequence, "Parliament, whose members represented many trades injured by these special privileges," 57 enacted the famous Statute of Monopolies of 1623. ${ }^{58}$ For this reason, the Statute of Monopolies has been fondly but erroneously called, the Magna Carta of the Right of Inventors. ${ }^{59}$ As I had already shown, the initiatives introduced by the Statute of Monopolies had clearly been provided for in the Venetian statute nearly 150 years before the enactment of the Statute of Monopolies. Consequently, the Statute of Monopolies is not the juridical origin of the modern patent system. It is therefore ironic that a subsequent legislation designed to rescue the tarnished integrity of the patent system as encapsulated in the Venetian patent statute assumed greater historical significance than the pioneering law itself.

However, the modern patent concept in its substance, procedure and political economics owes significant debts to the era spanning from the Medieval ages until the late nineteenth century of European industrialization. ${ }^{60}$ In other words, certain substantive

56 W.S. Holdsworth, "The Commons Debates 1621" (1936), 52 Law Quarterly Review 481.

57 Robert Merges, Intellectual Property, supra note 20 at 125. See the famous suit in Darcy v. Allin otherwise known as the Case of Monopolies, 77 E.R. 1263 or (1602) Co. Rep. 84. See also Richard Gardiner, "Industrial And Intellectual Property Rights: Their Nature And The Law Of The European Communities" (1972), 88 The Modern Law Review 507.

${ }^{88}$ Statute of Monopolies (21 Jac. 1., cap 3.) Although the Statute of Monopolies has received favourable reviews by scholars, it did not in fact dispense with monopolies per se. The Royalty maintained residual powers to grant monopolies for the importation of arts or products in England.

${ }^{59}$ George Francis Takach, Patents: A Canadian Compendium of Law and Practice (Edmonton: Juriliber, 1993) at 3; J. Vojacek, A Survey of the Principal National Patent Systems (New York: Prentice Hall, 1956) at 97-981.

${ }^{60}$ Brad Sherman and Lionel Bently, The Making of Modern Intellectual Property Law - The British Experience, 1760-1911 (Cambridge: Cambridge University Press, 1999) at 209. 
principles in the law of patents were developed and elaborated upon during the period of the industrial revolution. First, in reshaping the substance of patent law, ideas and discoveries of "natural" phenomena or laws, were debarred from the scope of patentability. Second, although the terms "invention" and "manufacture" had been enmeshed in importation or introduction of already existing trade or technologies, latter medieval patent law and practice was becoming heavily dominated by, if not exclusively restricted to genuine mechanical inventions. ${ }^{61}$

Third, prior to the evolution of corporate legal personalities and commercial capitalization of the industrial and inventive process, the patent concept was anchored on the individualism of the inventive process. ${ }^{62}$ Fourth, given the requirements of industrialization in Europe, the requirement of industrial repeatability or industrial applicability of patented subjects became a regular feature of modern patent law and practice. ${ }^{63}$ Fifth, the requirement of registration of patents also originated during the period in question, precisely, from the provisions of the British and French designs laws regulating ownership of new textile designs. By this law, it was incumbent on applicants for ownership of new textile designs to specify their designs and show how those designs differed from previously registered designs. ${ }^{64}$

61 Seaborne Davies, "The Early History of the Patent Specification" (1934), 50 The Law Quarterly Review 86 at 95; Jerome Reichman, "Charting the Collapse of the Patent-Copyright Dichotomy: Premises for a Restructured International Intellectual Property System” (1994), 13 Cardozo Arts \& Entertainment Law Journal 475.

${ }^{62}$ This may also be attributed to the influence of the Calico Printers'Act of 1787 on patent law. According to Sherman and Bently, "the 1787 Act recognized the individual as the source of the design." See Sherman and Bently, ibid. As Erle J. held in Jefferys v. Boosey (1854) 10 ER 702, "... a person to be entitled to the character of an inventor must himself have conceived the idea embodied in the improvement. It must be the product of his own mind and genius and not of another's." (Emphasis added)

${ }^{63}$ The Designs Laws in England initiated the bureaucratic control of the patent system. According to Sherman and Bently, the first of such laws was the Calico Printers' Act of 1787. See Wyndham Hulme, "The History of the Patent System under the Prerogative and at Common Law" (1896), 12 The Law Quarterly Review 141; Wyndham Hulme, "The History of the Patent System under the Prerogative and at Common Law - A Sequel" (1900), 16 The Law Quarterly Review 441. As an aside, Nedd Ludd's rebellion in 1811 against the emerging industrial revolution in the English Midlands marked the pejorative term of "Luddites" reserved for those opposed to new technologies.

${ }^{64}$ The system of registration was designed to curtail arguments on originality. Prior to that, patents were being routinely granted on already patented inventions. See Seaborne Davies, supra note 61 at 96; Dundas White, "The New 'Investigation' For Patents" (1903), 19 The Law Quarterly Review 307. These requirements are particularly suited to peoples with pronounced culture of writing. For a short but informative account of the influence of the British textile laws on the fledgling patent regime, see Kathy Bowrey "Art, Craft, Good Taste And Manufacturing: The Development of Intellectual Property Laws" (1997), 15 Law in Context 78. The history of 
The requirement of registration thus laid the foundations for the corollary procedural requirement of specification of patent applications. The requirement that the applicant for a patent describe his or her invention clearly and completely is judicially associated with the 1778 opinion of Lord Mansfield in Liardet v. Johnson. ${ }^{65}$ The specification is a technical outline and description of the invention.

In theory, the specification is a form of consideration for the patent grant. In this sense, a patent has been said to be as good as its specification. Specifications largely transformed the patent system, at least in theory, from a mechanism for importing existing technologies (in the immediate post-Venetian patent system era) into an institution for rewarding those inventors who created new and useful machines. In this regard, the industrial revolution could be said to have contributed to the refinement of the patent system.

In spite of the Statute of Monopolies and similar juridical initiatives designed to confer legitimacy and credibility on the patent system, by the mid-nineteenth century, the patent system had become a cesspool of bureaucratic bungling, complex and expensive process of registration and general juridical confusion. ${ }^{66}$ Coupled with a rising public preference for a regime of laissez-faire in trade and ideas, there was a widespread call for the abolition of the patent system in England, ${ }^{67}$ continental Europe and in the United States. In 1863, the parliament in Germany condemned the patent system as being "injurious to common welfare" and the Government of Prussia opposed the adoption of the patent system by the North German Federation. Otto von Bismarck, then Chancellor of the North German Federation captured the popular opinion when he noted that it was better to abolish the patent system "rather than to engage in hopeless attempts to reform the system." ${ }^{\text {"6 }}$

In Switzerland, the leading economists characterized the patent system as "pernicious and indefensible" 69 and a group of industrialists argued rather passionately that "in the interest of the general prosperity of industry and trade, patent protection, that

British industrialization, and impliedly, global industrialization, would be incomplete without reference to the British textile industry.

65 (1778) 1 Web Pat Cas 53. For a detailed account of the history of the specification requirement, see Seaborne Davies, supra. See Bainbridge v. Wigley (1810) 171 ER 636; Wyndham Hulme, "On The Consideration Of The Patent Grant, Past and Present" (1897), 13 The Law Quarterly Review 313.

${ }^{66}$ For a judicial account of the patent controversy of the nineteenth century see Attorney-General v. Adelaide Steamship Co., [1913] A.C. 781.

${ }^{67}$ Sherman and Bently, supra note 60 at 131-132.

${ }^{68}$ Schiff, supra note 7 at 21; Stephen Ladas, supra note 31 at 285.

69 Abbott, supra note 11 at 228 . For a detailed account of the patent controversy, see Fritz Machlup and Edith Penrose, "The Patent Controversy in the 19th Century" (1950), 10 Journal of Economic History 1-29. 
cup of sorrows"70 should pass them. Opinions such as this won the day in the Netherlands and Japan. Hence the Dutch abolished it in 1869 and Japan, which had adopted a patent law in 1872, abolished it 1873. Across the Atlantic, the United States' House of Representatives followed suit and enacted a bill abolishing the patent system. However, by a handful of votes the bill failed passage at the Senate. ${ }^{\text {1 }}$

Opposition to the patent system began to collapse in 1873 as a probable result of the great economic depression and the consequent rise of protectionism, economic nationalism, heavy and intensive lobbying by manufacturers, and above all, the willingness of the patent advocates to accept the principle of compulsory licensing as part of the "reformed" patent law. ${ }^{72}$ Britain relented in 1874, Germany in 1877 and Japan reenacted a patent law in 1885 . Switzerland enacted a patent law in $1887 . .^{73}$ Since then, patents have become an accepted part of both domestic and international legal regimes.

\section{Conclusion}

In sum, the system of patents, with its convoluted origins in the Italian peninsula, preceded the industrial revolution in Europe. Therefore, the "historical necessity" argument, often touted by advocates of the patent system is not supported by the history of the patent system. In a classic study of the relationship between patents and the British industrial revolution, W.H. Price concluded as follows: "in the mechanical process that took place in the 16th and 17th centuries, patents were not the leading factors. Some of the most successful mechanical innovations of the period did not enjoy any patent." ${ }^{14}$ Similar studies by Ashton, ${ }^{75}$ Deane ${ }^{76}$ and Mathias, ${ }^{77}$ "all hesitate to assert a causal relationship" ${ }^{178}$ between patents and the industrial revolution. Indeed Ashton's studies show that on some occasions, the patent system blocked the "way to new con-

\footnotetext{
70 Schiff, supra note 7 at 87.

71 Bugbee, supra note 34 at 109.

72 Schiff, supra note 7 at 34.

${ }^{73}$ Schiff, ibid.

${ }^{74}$ W.H. Price, English Patents Of Monopoly (Boston: 1906) at 62.

75 T.S Ashton, The Industrial Revolution, 1760-1830 (Oxford: Oxford University Press, 1948).

${ }^{76}$ Phyllis Deane, The First Industrial Revolution (Cambridge: Cambridge University Press, 1965).

77 Peter Mathias, The First Industrial Nation: An Economic History of Britain (New York: Charles Scribner's Son, 1969).

${ }^{78}$ Coulter, supra note 39 at 3 . According to Coulter, "the question of whether patents for invention served as a stimulus to or a drag upon inventive activity during the industrial revolution will probably remain open." Coulter, supra at 23. But see Gerald Mossinghoff, "The Importance of Intellectual Property Protection in International Trade" (1984), 7 Boston College International \& Comparative Law Review 235.
} 
trivance" ${ }^{79}$ And in his view, discovery and innovation might have "developed equally rapidly without the patent system." ${ }^{80}$

Schiff's study of inventiveness and patent institutions in eighteenth century Netherlands and Switzerland led him to the conclusion that "inventive activity can be quite vigorous in countries without a patent system" ${ }^{81}$ Interestingly, the Netherlands repealed its patent laws in 1869 and the Swiss had no national patent law until 1888, yet both countries during their "patentless" periods witnessed inventiveness and industrialization. In his view, a study of history shows that "patents have not been synonymous with inventions" ${ }^{82}$ In modern times, certain industries such as the brewing, pottery, and automobile industries, that largely operate outside the patent regime, have made enormous strides in innovativeness and inventions. In sum, it seems that the preponderance of reasoned opinion and empirical research is that "the industrialization of a country can proceed smoothly and vigorously without a national patent system." ${ }^{83}$

Be that as it may, it is evident that early European industrial history fails to support the argument of a direct causal link between the patent system, inventiveness and the industrial revolution in Britain or elsewhere. According to Ulf Anderfelt, "in a study of the birth and decline of early patent systems in some continental countries, ... the conclusion (by Frumkin) appears to be that the patent institution followed rather than preceded the economic and cultural development and later lost its importance when these activities became less intensive." ${ }^{44}$ Deriving further support from the Venetian patent system, Anderfelt's studies further show that:

[T]he existence of the Venetian Patent Act, and of early patent systems in some other continental countries, is interesting from another point of view. The idea so cherished by the patent advocates, that there exists a more or less organic relationship between the existence of a patent law and the economic and industrial performance of a country, cannot be supported at all by this early experience. In Venice the patent system was introduced when that state was already at the height of its development. ${ }^{85}$

79 Ashton, supra note 75 at 10 . The example of James Watts's quarter century domination of steam engine construction in Britain comes handy in Ashton's conclusions. But see David Landes, The Unbound Prometheus: Technological Change and Industrial Development in Western Europe from 1750 to the Present (Cambridge: Cambridge University Press, 1969) at 199; H.I. Dutton, The Patent System and Inventive Activity during the Industrial Revolution (Manchester: Manchester University Press, 1984) at 104.

${ }^{80}$ Coulter, supra note 39 at 23.

${ }^{81}$ Schiff, supra note 7 at 5 .

${ }^{82}$ Macleod, supra note 43 at 158.

${ }^{83}$ Schiff, supra note 7 at 124.

${ }^{84}$ Anderfelt, supra note 36 at 6.

${ }^{85}$ Ibid. For the early German experience, see H. Pohlman, "The Inventor's Right In Early German Law" (1961), 43 Journal of the Patent Office Society 121. 
In summary, the argument by patent advocates that the patent system is coterminous with industrialization of Europe or that the patent system is a historical necessity is not supported by the history of industrialization and the practice of States in Europe. ${ }^{86}$ Accordingly, it would be simplistic and sweeping to attribute modern industrial attainments to the patent system.

Perhaps, the stronger and more defensible argument for a patent system has been articulated by Judge Simon Rifkind, Co-Chairman of the famous United States President's Commission on the Patent System. In his words:

[T] he really great, creative geniuses of this world would have contributed their inventions even if there were a jail penalty for doing so. But that in itself would not have been sufficient. The patent system is more essential to getting together the risk capital which is required to exploit and to develop and to apply the contributions of the genius inventor than to provide a stimulus for the actual mental contribution. It is to the former that the economic incentive is indispensable. The money will not be risked unless there is some sense of assurance that a benefit will be obtained. ${ }^{87}$

Judge Rifkind's acute observation makes eminent sense. What is rather surprising however is that most advocates of the patent system have engaged in a skewed reconstruction of the history of the patent systems in other to demonstrate a non-existent historical linkage between patents and industrialization, especially, during the medieval era.

\footnotetext{
${ }^{86}$ According to one of the chief proponents of the "historical necessity" argument, "the patent system is not the result of inspired thinking but is a dictate of historical necessity." See H.G. Fox, Monopolies and Patents: A Study of the History and Future of the Patent Monopoly (Toronto: University of Toronto Studies, Legal Series, Extra Vol., 1947) at 190. But see Anderfelt, supra note 536 at 27.
}

87 Report Of The President's Commission on the Patent System, reproduced in Hearings Before Subcommittee No. 3 of the Committee on the Judiciary House of Representatives, 90th Congress on H.R. 5924, H.R. 13951, and related Bills for the General Revision of the Patent Laws, Title 35 of the United States Code, and For Other Purposes, Serial No. 11, Part 1 (Washington: U.S. Government Printing Office, 1968) at 170. Compare with, Jay Erstling, "The Protection of Intellectual Property - of Metaphysics, Motivation, And Monopoly" (1991), 3 Sri Lanka Journal of International Law 51. 